\title{
The Horror! The Horror! Saw, Torture and Surveillance
}

\author{
John Boccanfuso \\ Stockholm School of Theology, Bromma, Sweden
}

\begin{abstract}
This article mainly tells something about horror films, torture and surveillance. They love films because they are scopophiles. This comes into play especially when they are watching horror films.They will focus on the films Saw, particularly the first two in the franchise, and attempt to tease out what about these films makes them such a desirable spectacle for moviegoers and also what philosophical ideas may be at work in them.
\end{abstract}

Keywords: film, saw, torture and surveillance

\section{Introduction}

They love films because they are scopophiles. They love to look. It is a basic part of them all, and not just when it comes to watching films; they watch people all the time, and they are constantly looking at things they find pleasing and looking away from things they do not think so. But, in some instances, they also find ourselves looking at things they do not find pleasing and deriving a certain pleasure from that as well.

This comes into play especially when they are watching horror films. Whether they are supernatural (ghosts, demons, curses and aliens) or natural (serial killers, the insane and stalkers), they get a kind of pleasure from the horrific images on screen. There is something about seeing others in pain that both excites and disturbs them as movie watchers; they not only love to look, but also love to be scared. Since about 2005, there has been a trend in horror films that takes the idea of excitement and disturbance to a more graphic level than ever before, referred to as "torture porn", the main features of which include a seemingly mindless display of physical and psychological torture and dismemberment.

In an article published in New York Magazine (2006, Jan 28), film critic David Edelstein first coined the termed "torture porn", a descriptor used for a subgenre of horror films which became popular in the mid-2000s. Edelstein's article primarily focused on Eli Roth's film Hostel, which was released to enthusiastic audience response in the early 2006, but the term has grown to include several horror films: Wolf Creek, The Devil's Rejects, two sequels to Hostel, and the seven-film Saw franchise. According to Edelstein, torture porn films contain "explicit scenes of torture and mutilation" (Edelstein, 2006). This would seem par for the course in the horror genre, but Edelstein(2006) argues that:

"...torture movies cut deeper than mere gory spectacle. Unlike the old seventies and eighties hack-'em-ups... in which masked maniacs punished nubile teens for promiscuity (the spurt of blood was equivalent to the money shot in porn), the victims here are neither interchangeable nor expendable. They range from decent people with recognizable emotions to, well, Jesus”.

\footnotetext{
John Boccanfuso , School of Buisness , Stockholm School of Theology, Sweden.

Correspondence concerning this article should be addressed to Macomb, Illinois, 1981. Email: johnboccanfuso@rocketmail.com.
} 
Why are audiences so drawn to this type of film? Whether or not they fall into Edelstein's category of torture porn, gory horror films are not something new. As Edelstein (2006) mentions, there were several successful gore spectacles in past decades, among them some of the most enduring horror franchises such as Halloween, Friday the 13th and A Nightmare on Elm Street. But the focus became something "extraordinarily cruel"; filmmakers realized that "in the quest to have a visceral impact, actual viscera are the final frontier". So a new subgenre of horror was born, one that combines the expected gore but presented in a way that is not campy or symbolic, as Edelstein (2006) mentions above: it is gruesome, random, and relentless.

So, again, why is this type of film so popular with audiences? Is there more to them than simply the "visceral impact?" They will focus on the films Saw, particularly the first two in the franchise, and attempt to tease out what about these films makes them such a desirable spectacle for moviegoers and also what philosophical ideas may be at work in them.

\section{See-Saw}

So much of the early Saw franchise depends on viewing, looking and seeing as extensions of the primary villain's, John "Jigsaw” Kramer, pleasure. They discover early in the first film that John is suffering from terminal cancer; as the films progress and the audience gains more of John's back story, they realize there have been a series of events in his life which have tested his faith and his will to live. As he dies, he observes these events in the lives of strangers; but he is no longer willing to sit back and allow the matters to play out as they will. John "tests" these people, pushing them to the limits of their own mortality to discover just how far they will go to stay alive: an option he no longer has but always chose in the past. In subsequent films, they see John's child miscarried and his marriage crumbled, which lead to a botched suicide attempt. This event in particular activates what John calls in Saw II his "survival instinct", and he attempts to bring the same out of others by placing them in situations of psychological torture with only two options: survive or die, with neither option being the clear winner.

It will touch upon the spectacle of the torturous situations themselves in a bit, but it would be remiss without first discussing the film franchise's title: Saw. It's a multi-layered title for the first film in the series, referring to many physical and figurative objects. The film opens with two men chained to pipes in a decrepit, subterranean bathroom; the other things in the room are cassette players and a dead body. As the two men listen to the cassette and begin to play Jigsaw's survival game, other objects are revealed, including a pair of hacksaws. The idea of the hacksaws is that they are the survival tools: By sawing off their own feet where they are chained, the men may go free rather than wasting away in the room. So the title very obviously refers to the hacksaws, the cruel and gruesome means of escape. It also refers to the killer's name: Jigsaw, whom we later discover is John Kramer. John gains the nickname from his deceased victims, all of whom have a piece of flesh removed from their corpses in the shape of a jigsaw puzzle piece. We learn in Saw II that this symbolized that the dead are "missing a vital piece of the human puzzle: the survival instinct". So the title also refers to the villain. But there is another use of Saw as a title, in a different part of speech: as a verb. "Saw" can also refer to the past tense of "to see", which comes into play heavily (and directly) in the first two films, and indirectly in the latter films.

It is explained fairly early in Saw that the Jigsaw killer always has an alcove from which to watch his subjects as they attempt to complete his "tests". He cuts holes into walls and sets up security cameras, etc. So that he may have a front row seat to the carnage. This is taken to the next level when they discover at the film's 
conclusion that the supposedly dead body in the bathroom has been watching the whole scene unfold: It is John. This idea of seeing, and what one has seen, is developed further in Saw II, when security cameras play a central role in the film's story. Jigsaw kidnaps a detective's son, forcing the detective to play one of his games in order to retrieve his child; a concurrent game is played out via security cameras. If the detective watches the eight people playing the other game die, his son will be returned safely. They later learn that the security footage is pre-recorded, and the detective's son is actually locked in a safe; but because he does not follow John's rules, the detective is put through his own test as the film concludes. Even the title, Saw II, can be read as Saw Too, meaning "also saw". In the first film, it is only Jigsaw who gets to watch his tests in progress, but in this film, the audience (and other characters, such as the detective) get to see the tests happen as well.

This all adds another level to the already-complicated scopophilia of film. They, the audience, are watching a film, which someone else has framed through a certain lens (and we cannot see anything outside of that frame); in that film, we are watching Jigsaw watching his tests, and also watching his tests simultaneously. So Saw Too can mean "saw more", which they are allowed to do in the sequel more than they are in the original. In the original, they had access to John's games only through quick cut flashbacks, which are framed as possibly being how the police "see" the deaths, not necessarily how they actually happened; in the sequel, they are given firsthand access to Jigsaw's games as he sees them and as they really happen. This connection becomes more tenuous as the films progress (there are seven in total), but that is likely due to the fact that John Kramer kills himself in the third film and only appears as a disembodied voice in present time from thereon out; they can no longer see what Jigsaw sees because he is dead. The act of viewing gets as saturated as it possibly is by the end of Saw II.

All of this set up a discussion of how the torturous situations, which are called "traps" in the film series, become a spectacle in and of themselves. They can also very clearly see examples of surveillance and monitoring in each of the films, particularly the first two, which are the ones they will be limiting themselves to in this discussion.

\section{A Modern Day Panopticon: Foucault in Saw}

The traps in the Saw films are based on three principles: isolation, surveillance, and punishment. These are the same principles at the core of the Panopticon as described by Jeremy Bentham and reified by Michel Foucault in Discipline \& Punish: The Birth of the Prison. Bentham's Panopticon, described in 1791, was a standard for isolating the plague, a means of constant surveillance: imprisonment, constant guarding, etc. The Panopticon is the ultimate means of surveillance, of keeping watch on prisoners at all times. This in and of itself is a way of controlled spectacle, creating a voyeurism meant only for the privileged few who have the power to be on the outside. Foucault(1995) writes: "The gaze is alert everywhere" (p.195). And this is true: there are eyes everywhere, attempting to prevent the spread of disease. The Panopticon is the ideal prison because of this:

"This enclosed, segmented space, observed at every point, in which the individuals are inserted in a fixed place, in which the slightest movements are supervised, in which all events are recorded, in which an uninterrupted work of writing links the centre and periphery, in which power is exercised without division, according to a continuous hierarchical figure, in which each individual is constantly located, examined and distributed among the living beings, the sick and the dead-all this constitutes a compact model of the disciplinary mechanism”. 
Most, if not all, of the above tenets of the Panopticon can be found in some capacity in the traps of Jigsaw. Take the primary trap in the original film Saw for example: Dr. Lawrence Gordon and Adam Stanheight are chained to pipes in a bathroom with two hacksaws, a cassette player, two bathtubs and toilets, and a dead body between them. Even before the "game", as Jigsaw calls it, begins, their situation resembles one of imprisonment. The heavy, steel door is open but they are chained by the ankles, preventing escape. The floor is cold tile, and the lighting is fluorescent but dim.

As the film progresses, more relationship to the Panopticon is revealed. Gordon and Adam are being surveyed and recorded constantly by security cameras behind two-way mirrors. In other traps, they learn that Jigsaw cuts holes into walls or watches from the security cameras himself. Once the cassette is played, it becomes clear that Jigsaw is the "hierarchical figure" of the previously-quoted passage. The body in the center of the room represents the "sick and dead"; this is furthered by Dr. Gordon's occupation as an oncologist, one who is surrounded by the sick and dying at all times. Jigsaw even makes reference to this in the cassette recording played early in the film: "Everyday of your working life, you have given people the news that they are going to die soon. Now you will be the cause of death". This brief, recorded monologue also references the body in the room: "When there's that much poison in your blood, the only thing left to do is shoot yourself". They, and the two characters, are led to believe that this "poison" kills one slowly and painfully, much like the plague would have.

But the phrase that keeps sticking out, particularly as it would relate to Jigsaw, is "in which power is exercised without division”. As mentioned previously, Jigsaw designs his traps in such a way that there are only two options: painful escape or death. Neither option is very palatable. In placing his victims in these situations, he is asserting the ultimate power: over life and death. He is leaving the option of which is chosen to the victim, but he is ultimately controlling whether they live or die. This is true of all horror films which feature a serial killer, but the way in which Jigsaw positions himself makes him all the more powerful. He has the power to control whether his victims live or die without actually taking their lives. It comes down to each victim to decide his or her fate. Jigsaw enforces the discipline and punishment of imprisonment without having any blood on his hands, so to speak.

Even this idea ultimately follows the rules of the Panopticon: "It lays down for each individual... his well-being, by means of an omnipresent and omniscient power... even to the ultimate determination of the individual, of what characterizes him, of what belongs to him, of what happens to him” (Foucault, 1995). Jigsaw ultimately gives the victim the power to determine "what happens to him", but not without giving up his "omnipresent power". The idea that Jigsaw is "omnipresent and omniscient" is hammered home when he is revealed to be the body in the bathroom with Gordon and Adam. Not only has he been surveying his victims with video recordings, he was with them the entire time.

Whereas the original is a literal prison, Jigsaw's Panopticon is more subtle. He still imprisons his victims (for example, if Jigsaw's rules are not followed and the game completed in a certain timeframe, the door will be closed and the imprisonment will be permanent and deadly — which is precisely Adam's fate when he does not cut off his own foot), and they are still constantly subtly surveyed. In Bentham's Panopticon, the surveillance is from a tower at the center of a circular building and from guards; in Jigsaw's, it is from security cameras and two-way mirrors, though he also acts as the guard as well. He subscribes to the "three functions" of the dungeon ("to enclose, to deprive of light and to hide”), as most of his traps take place in subterranean locations and are controlled from a secret hideout location; and to "the major effect of the Panopticon: to induce in the inmate a 
state of conscious and permanent visibility that assures the automatic functioning of power" (Foucault, 1995).

As Foucault (1995) points out later, "The Panopticon was also a laboratory; it could be used as a machine to carry out experiments, to alter behavior, to train or correct individuals.... To try out different punishments on prisoners, according to their crimes and characters, to seek the most effective ones ".

This is precisely Jigsaw's intent. For every victim he captures and imprisons, the trap is tailor made to suit whatever "crime" he believes the person to have committed. For a man who cuts himself without truly wishing to commit suicide, he must crawl through barbed wire; for a man (Dr. Gordon) who saves lives as a doctor, he must now take one (Adam); for a heroin addict, she must dig through a pit of discarded, dirty needles; for a man who has feigned illness, he must retrieve a code to enter a safe with an antidote to a slow-acting poison in his system; and so on. Each trap, each game, is imagined with the victim's history in Jigsaw's mind. And all because John Kramer is “sick of people who don't appreciate their blessings” and wants each victim to escape, to change themselves for the better and appreciate the mere fact that they have the privilege to live while he has a death sentence.

None of this is particularly surprising, if Foucault is to be believed. He argues that the Panopticon, as an idea and not so much a physical prison, is a form of discipline that can be "transferred and adapted" (Foucault, 1995). He believes that discipline is a mechanism that isn't enforced just by enclosed institutions, but as "centers of observation disseminated throughout society" (Foucault, 1995). Discipline and punishment are not reserved solely for law enforcement agents but can be instituted by schools, religion, and individuals. In the case of Saw, Jigsaw is the law.

They see the law of Jigsaw take precedence over the law of the land throughout the Saw films; in each case, one or more policemen are leading characters, looking to bring down Jigsaw's operation and subject him to the disciplinary mechanism of the justice system. But, ultimately, Jigsaw prevails in nearly every instance. In Saw and Saw II, the police, these traditional figures of discipline and punishment, fall victim to Jigsaw's "transferred and adapted" power schema: Tapp, the first film's lead detective, is murdered trying to prematurely end one of Jigsaw's games; and Eric Matthews, the second film's lead detective, ends up as one of Jigsaw's future victims when he becomes entrapped in the same bathroom as Dr. Gordon and Adam in Saw. Foucault (1995) states that "police power must bear 'over everything"” but that is untrue of the world Jigsaw seeks to change: Here, it is the power of the individual. Jigsaw is simply becoming what Foucault (1995) once predicted:"What is now imposed on penal justice as its point of application, its useful object, will no longer be the body of the guilty man set up against the body of the king; nor will it be the juridical subject of an ideal contract; it will be the disciplinary individual".

Jigsaw becomes this "disciplinary individual", instituting a new set of laws in which if one is not satisfied with life, he or she may have to fight for it or die. And this doesn't end with Jigsaw's death at the conclusion of Saw III; there are four subsequent films dealing with "apprentices” Jigsaw has trained to carry on his work, one of whom is, ironically, a police officer. In each instance, while the master and/or apprentice(s) may die, the work still lives on with a new disciple. Even the last film, subtitled "The Final Chapter" on its home media release, concludes with an open end and a new figure following Jigsaw's panoptic laws, further embodying Foucault and his idea that "the ideal point of penalty today would be an indefinite discipline" . Jigsaw dies, but the games continue indefinitely.

\section{The Spectacle of Torture}


Throughout history, torture has been a matter of spectacle. For hundreds of years, public executions, hangings, tortures, and imprisonments have been consumed by the masses with zeal. In America's past, the most obvious and (now) horrifying example is lynching. In contemporary times, public executions are no longer a vogue, but society has replaced those with other public displays of torture and murder, namely in graphic films and photos. Less than 10 years ago, there was the scandal involving a group of American soldiers at the Abu Ghraib prison in Iraq. The Americans, acting as prison guards, sexually, physically, mentally, and emotionally tortured a large group of Iraqi prisoners and then photographed it. Graphic depictions of prisoners forced to masturbate alongside other men, stacked nude on top of each other, beaten, etc, were suddenly making the rounds in American media. They recall the bygone photographs of lynching: "There is, of course, a long history of making subaltern bodies suffer for the pleasure of dominant groups in America... This secret pleasure, widespread as it is, cannot be publicly acknowledged” (Mirzoeff, 2006, p. 29). In commenting on the Abu Ghraib photos, Mirzoeff (2006) explains that the difference between this torture and lynching is that the latter is always visible and public, while the Abu Ghraib torture took place behind closed doors.

So what can be made of the public torture of fictional characters on film? What makes fictionalized torture so widely acceptable and "publicly acknowledged", while the same does not hold true for actual torture? And not only that, but why do torture porn films flip the audience's sympathy in a way that makes them identify with the killer rather than the victim?

The horror genre has always somehow elicited a response from its audience that makes them root for the killer. They see deflowered virgins and drug-addled teenagers on screen and not only expect but wish for them to meet with death. It's a convention of the genre, but as Dave Edelstein (2006) points out "something has changed in the past few decades". On the subject of serial killers, including villains such as Jigsaw, he writes that "as potential victims, we fear them, yet we also seek to identify with their power". They think the same can be said of the soldiers in the Abu Ghraib scandal. As revolting as some of the released photographs may be, there is still a large section of the American population who don't agree that any boundaries were crossed; this is possibly because of films like Saw.

In Saw, Jigsaw is portrayed as a kind of martyr. He is doing righteous work: attempting to get his victims to change themselves for the better, to appreciate the fact they have the privilege of merely existing. Taking that sentence at face value makes Jigsaw's bloody mission seem almost noble. But they must factor in the way this mission is gone about: by drugging, kidnapping, entrapping, and potentially killing people. The audience, for some reason, identifies with Jigsaw and anxiously awaits the invention of his next trap and the potential death of his next victim.

This is directly in line with the Abu Ghraib situation. The Iraqi inmates are portrayed in the media as the enemy, as terrorists, so the soldiers' torture of them is justified. "Our righteousness is buoyed by propaganda”, Edelstein (2006) writes. And he is correct. Torture has become something of a unifying element in American culture. When Osama bin Laden was killed, millions of Americans demanded to see photos proving his death. There is nothing moral about such photos, but they forget that in the wake of 9/11. That fateful day has made each American afraid: afraid of outsiders, of anyone who does not meet their moral standard, of becoming victims themselves. They crave retaliation, justice, balance, and something they can never get back: the world the way it used to be before we were constantly afraid.

In the current global landscape, "fear supplants empathy and makes us all potential torturers" (Edelstein, 2006). So when they see someone like Jigsaw in any of the several Saw films, they empathize with him. He is 
doing what they all subconsciously wish they were doing: torturing the wrongdoer. It's no coincidence, then, that the torture porn genre only came about post-9/11, occurring concurrently with the Abu Ghraib torture. Both the political scandal of Abu Ghraib and the cultural phenomenon of torture porn films are linked to the American desire for vengeance descended from the tragedy of 9/11.

Of course, this is just one theory. Because splatter films have origins back in the 1970s and almost all modern horror films feature extensive scenes of gore and/or torture, this link to 9/11 doesn't fully explain film's preoccupation with torture. There is the very basic desire of seeing someone else experience a misfortune that they, the audience, will never have to have a kind of schadenfreude that comes from seeing others' failings.

\section{The Horror! The Horror!}

Can it really be so simple? The horror genre exists very simply as entertainment and always has. Rarely they have horror films tried to change the world or even to reflect it, but that is precisely why the torture porn subgenre can be explained as so popular. For so long the genre followed conventions and formulas, down to the letter. An audience could watch just about any "hack-em-up” slasher film, as Edelstein calls them, and knows who would survive to the end and sometimes even the order in which each character will die.

Then comes the torture porn genre. It is just as predictable (characters will die, and it will be gruesome) but it breaks the "suspension of disbelief" convention. It is far more likely, for example, that a previously sane man goes mad after receiving a death knell, kidnaps people, and tortures them than it is likely that a group of movie watchers will be picked off one by one by an invincible hockey-mask-wearing, machete-wielding serial killer at an abandoned children's summer camp. The traps in the Saw franchise may stretch the bounds of believability (particularly in the later films as they became more over-the-top and complex), but the central conceit preys upon their base fears as people. They can't predict the nature of those who are insane, and they don't know the conditions that have made them that way. This is especially timely considering the recent events in Newtown, Connecticut and at the Boston Maraton; these violent acts are not only inherently horrifying because of the brutal circumstances, but because they were random and unpredictable.

This is part of the reason horror films are so appealing to audiences. It gives the rush of danger without actually putting them into danger. They are constantly looking, constantly seeing, so they seek out things that will make the experience of looking and seeing more pleasurable. It's a bit unsavory to think that violence and torture are pleasurable, but when there is a distance between the viewer and the subject as there is in film, that's just the way it is. And if these films can also be a commentary on the way they are always seen, even as they are seeing others, then they are not wholly without merit as commonly believed.

\section{References}

Dir. James Wan.(2004). Saw. [Recorded by Leigh Whannell]. OnLionsgate Films[DVD].

Edelstein, David. (2006, Jan 28). Torture Porn: The Sadistic Movie Trend. New York Magazine. 1-2. Retrieved from http://nymag.com/movies/features/15622/

Foucault, Michel. (1995). Panopticism. Discipline \& Punish: The Birth of the Prison (PP.195-228). New York: Vintage Books.

Michel, $\quad$ Foucault.(1975). Panopticism. Discipline \& Punish $\quad$ Retrieved from http://foucault.info/documents/disciplineAndPunish/foucault.disciplineAndPunish.panOpticism.html

Mirzoeff, Nicholas. (2006). Invisible Empire: Visual Culture, Embodied Spectacle, and Abu Ghraib. Radical History Review. 95, 21-44. 